\title{
Mental Accounting in Household Financial Management (Study in Civil Servants of Senior High School Teachers in Sirimau District Ambon)
}

\author{
Micrets Agustina Silaya ${ }^{1}$, Chricella Natalia Joseph ${ }^{2 *}$, Dessy Balik ${ }^{3 *}$, Debby Likumahua ${ }^{4 *}$ \\ Faculty of Economics, Indonesian Christian University, Maluku \\ * Corresponding author: \\ Email: makawerumicke85@gmail.com \\ Abstract. \\ Objectives-Financial management is the process of systematically \\ carrying out financial resources to meet the needs of life. In financial \\ management, a person often thinks partially, thus causing illogical use \\ of money because of the mental accounting aspects of the individual. \\ This research aimed to analyze mental accounting in household financial \\ management of civil servants of senior high school teachers in Sirimau District \\ Ambon. Methods - This research was a descriptive study. The sample in \\ this research was civil servant of high school teachers in Sirimau District \\ Ambon. The research was carried out by distributing questionnaires \\ directly to the high school teacher in Sirimau district Ambon. The analysis \\ technique used in this research is descriptive statistics using frequency distribution. \\ Results - The research results indicate that there is a mental acoounting \\ in household financial management. This can be seen from the behavior \\ that tends to classify and enforce differently depending on where the \\ money comes from. In this research, mental accounting is used as a self \\ control in the sense that it does not have a biased effect but a good one. \\ Keywords: Financial Management, Behavior Finance, Mental Accounting, Civil \\ Servants of Senior High School Teachers
}

\section{INTRODUCTION}

The decision-making situation faced by individuals influences the success of decision making. Most individuals are not able to distinguish between primary and secondary needs, and assume that they are the same. Sometimes the need comes suddenly and there is no priority scale. This results in individuals experiencing financial problems and must cover these deficiencies with loans. Households tend to increase their consumption (overspending) by making loans rather than increasing the amount of savings [1]. This means that salary increases are often asymmetrical with the increases in savings, but symmetrical with the increases in loans. Furthermore, it is said that this phenomenon in behavior-based finance is known as mental accounting, that is, someone often thinks partially. The reason someone makes decisions in financial terms can be explained by the term "mental accounting; a phenomenon of financial behavior or behavioral finance that was first examined by Richard Thaler. Mental accounting is an economic behavior when someone classifies inputs and outputs based on items just like the accounting model (account code). [2]

For example, this can be seen from the behavior of a civil servant with their thirteenth and fourteenth salary. In recent years, every year civil servants get a thirteenth salary, a salary equal to one full monthly salary. A civil servant, I Ketut Payu (not the real name), received his thirteenth salary as much as Rp. 3,500,000. - He saved all of this salary in a government bank. None of the salary was used for other purposes, especially for fun. This behavior is very different from I Nyoman Gampil (only pseudonym), his co-worker. He chose to buy a 29 -inch television, a DVD player, and a television rack. Of the thirteen salary he received amounting to $\mathrm{Rp} 4,145,000$, -, the $\mathrm{Rp} 3,600,000$, - used to buy electronic devices. The remaining Rp. 545,000, - spent in Bedugul for recreation with his family. The money ran out completely within two days for the two purposes. In the case of using the thirteenth salary, it can be seen that psychological and social factors determine a person's choices. Did I Ketut Payu make the right decision, while I Nyoman Gampil didn't? Whether or not the decision is right, depends on the mental accounting of each individual involved. Mental accounting occurs when first, someone thinks he is not a spender, but he himself has difficulty in saving, even though the individual income is quite large. Second, someone purchases more when using credit cards rather than using cash. Third, most individual pension funds are in fixed income or other 
inflation-prone investments. Fourth, the way someone treats Rp. 1 million from inheritance money is different from Rp. 1 million obtained from work (http://www. pratolo.com). A person often thinks partially so as to cause bias in decision making. For example, the consumptive phenomenon of household financial management in Ambon is based on observations of daily behavior. Not even a lot has been examining mental accounting on household behavior and the impact of such behavior. These things then encouraged researchers to conduct this research. In addition to everyday phenomena, mental accounting that has also been proven through many studies or experiments in various fields, can influence decision making, among others, first, consumer buying decisions including mental accounting and small windfalls [3], mental accounting is a future consumption control strategy [4], proportional bias towards the four principles in mental accounting [5]; [6]; [7]; [8]; [9], the role of bias in consumer behavior in mental accounting [10], how consumers evaluate accounts [11]. Use of money from different sources of income [12] and [13]. Second, investment decisions include mental accounting in portfolio choice [16], [17] and [18]. This research aims to analyze mental accounting in the household financial management of civil servants of high school teachers in Sirimau district Ambon. This research is arranged in five parts. The second section presents a literature review with the relevant authors, the third section discusses the methodology used and the fourth section presents and analyzes the results. Finally, in the fifth section, we present the main conclusions.

\section{RESEARCH METHODOLOGY}

\section{Prospect Theory}

Prospect theory is developed by [7] is the most developed theory in the study of financial behavior. Prospect theory describes how people often make decisions and assess decisions in risks and uncertainties. Kahneman and Tversky conducted their research on human behavior which was considered strange and contradictory in making a decision. The same research subjects were given the same choice but were formulated differently, and they showed two different behaviors. Kahneman and Tversky called this risk-aversion and risk-seeking behavior. The example they put forward is seen from people who want to go through almost all shops in a city to get $\$ 5$ cheaper for a $\$ 15$ calculator, but they won't do it to get $\$ 5$ cheaper for a $\$ 125$ jacket.

Individuals assessing profit and loss are based on the S-shaped function as shown in figure 1.1 where the function value is defined more than the profit and loss relative to the reference point rather than the level of wealth. Its function is concave and convex to the function value of profit and loss in prospect theory defined by a single outcome. Based on the value function, individuals will evaluate results that show that people will have an irrational tendency to be more reluctant to risk gain than loss. In a loss condition, someone will tend to be more inclined to bear the risk than in a successful condition. One will feel as if the value of losing a certain amount of money in a bet is more painful than the winning the value of the same amount of money, so that in a loss situation people are more determined to bear.

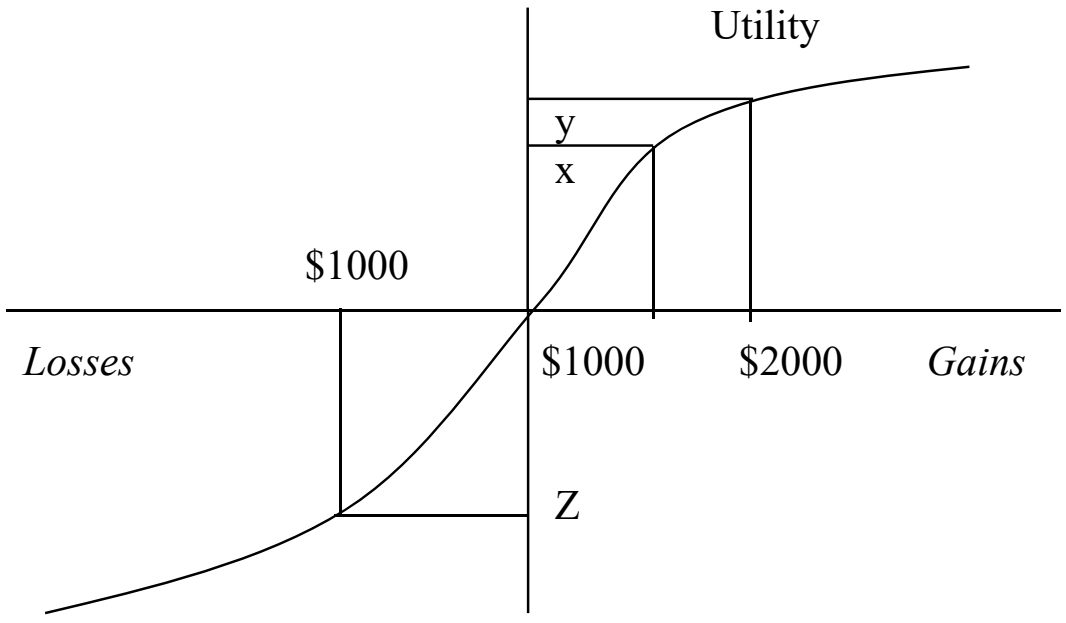

Fig. Prospect theory The psychological value of gains and losses

Source : Kahneman and Tversky (1979)

Kahneman and Tversky also proposed prospect theory as a descriptive model of decision making. In prospect theory, individuals maximize the value of functions rather than standard utility functions. Prospect 
theory is different from utility theory, among others; first, prospect theory replaces utility with value, where utility is usually defined as net wealth, while value is defined as profit or loss. Second, the value of the relative loss is not the same as the value of the profit. For example, people will feel more hurt if they lose Rp. 100,000, - compared to the excitement when gaining Rp. 100,000, -.Kahneman and Tversky (1979) [17] said people will tend to experience risk-aversion when facing profit and risk-seeking when facing losses.

\subsection{Mental Accounting}

Mental accounting refers to the process of identifying, categorizing, and evaluating results in finance. [18]; [12]; [19]; [20]). A phenomenon of financial behavior finance (behavioral finance) was first examined by Richard Thaler. [2] defines mental accounting as economic behavior when someone classifies inputs and outputs based on items just like accounting models (account code). According to the behavior life cycle theory, [21] assumed that people categorize assets (assets) in three accounts, including: 1) income flows, 2) current assets, and 3) future income. According to this theory, individuals assign different functions to each group of assets, which have irrational and frequent adverse effects on consumption decisions and other behaviors.

[18] stated that "mental accounting is the set of cognitive operation use by individuals and household to code, catagirize and evaluate financial activities". Likewise, Phung explained that mental accounting might be driven by the need to simplify decisions because of limitations in cognitive resources. [22]. Furthermore, [18] said there were three components in the mental accounting process; first, perceptions of outcomes and making and evaluating decisions; second, determining the activities for specific recording; and third, determining the limitation of the time period for other related mental accounting.

The example put forward by Suryobroto that is, a man from Indonesia is in Las Vegas. He needs to attend a seminar. At night, he told his roommate to try gambling machines in Las Vegas as an additional experience because he had never found the machines in Indonesia. He only brought $\$ 5$ and he headed to the jackpot machine. On the first try, the jackpot machine 'hit' and spit out $\$ 25$ for it. The man tried other jackpot machines and managed to raise $\$ 2,500$. Then he tried his luck at the blackjack table or card game and risked all that fortune of $\$ 2,500$ in the first game and won $\$ 10,000$. That continued until he finally got $\$$ $1,000,000$ (one million dollars). Then he moved to the roulette table and again risked all his money ( $\$ 1$ million). At the table, the money ran out and he returned to his hotel room. His friend asked, how good was his luck, and the answer was, "Not bad, I lost \$ 5". Suryobroto further said that when the amount of money is not written on paper and only "written" on a person's mentality, the money becomes worthless.

\subsection{Mental Accounting in Financial Management}

Stated that people treat money differently depending on the source. For example, people tend to spend more money, such as work bonuses and prizes, compared to the same amount of money that is usually expected, like from their salary. [22] This causes the use of money not logical due to the mental accounting aspects of the individual. Money in one mental account is not a perfect substitute for money in another account. One reason may be due to mental accounting, the cognitive process in which people treat different resources depending on the principle of economic fungibility [24].

Mental accounting refers to the behavior or way of thinking of someone who has a tendency to classify and treat money differently depending on where the money comes from. According to this theory, individuals assign different functions to each group of assets, which have irrational and frequent adverse effects on consumption decisions and other behaviors.[ 19]. Although many people use mental accounting, they may not realize how illogical this thought really is. For example, people often use "special money" savings for vacations or new homes, while their substantial credit or loan is still recorded. Or even householders prefer to use credit with a relatively high interest rate than the savings they have with relatively low interest from the banking sector for consumption purposes.

According to Thaler \& Shefrin; Shefrin \& Thaler, in Milkman and Beshears, mental accounting helps people manage their expenses in the face of the problem that with a budget that is only a certain 
amount of money in the consumption category, people may be more resistant to overspending. [2]; [21]; [25].

Individual behavior in managing finances is not only influenced by rational factors, but also there are irrational factors such as individual emotional attitudes that lead to actions without logic. This is because individuals often think partially or in behavior-based finance known as mental accounting.

\section{RESULT AND DISCUSSION}

\section{Type of Research}

This research tried to analyze mental accounting as well as its impact on the household financial management of Civil Servants of High School Teachers (SMA) in Sirimau district Ambon. Supramono \& Utami mentioned three types of research, among others, 1) exploration that is trying to build a theoretical framework, 2) descriptive, that is describing the characteristics of the variables to be studied, 3) explanatory that is looking at the relationship between several variables that can explain the hypothesis tested. Based on this, this research was categorized in the type of descriptive research. [26]

\section{Types of Data and Data Collection Techniques}

The type of data used in this research is data obtained through filling out questionnaires regarding mental accounting and its impact on financial management. To capture mental accounting phenomena in household financial management, a research instrument was developed from the concept of mental accounting. Mental accounting is economic behavior when someone classifies inputs and outputs based on items just like the accounting model (account code). [27]

Data collection technique used was field research, where research aims to obtain data or information directly from the object to be studied. Data collection was carried out by survey method with questionnaire technique.

\section{Analysis Technique}

The objective of this research was descriptive, that is to analyze mental accounting and the impact of mental accounting behavior in household financial management in Civil Servants of High School Teachers (SMA) in Ambon. Thus, the analytical techniques used to achieve the research objectives are descriptive statistics using frequency distribution and descriptive respondents' assessment of the results of the research variable answers.

\section{Characteristics of Respondents}

Based on questionnaires distributed to Civil Servants of High School Teachers (SMA) in Sirimau district Ambon, the characteristics of respondents were seen from age, class, number of family members, length of work, work of husband or wife (if any), average income per month, average income per month after deductions (if the respondent does not object), the average income per month of the husband or wife who works. Research respondents consisted of 78 civil servants of high school teachers.

The description of the characteristics of respondents in this research is the Civil Servants of High School Teachers (SMA) in Sirimau district Ambon from group III and IV, who have worked as teachers for more than one year, with the age of 24 to 58 years old and have a family, have more than 3 family members, and have income per average month of Rp. 2,400,000. Of the 78 Teachers, 37 of whom have an income of

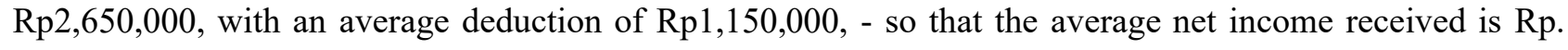
1,500,000. Apart from these 78 respondents, 52 people have a husband/wife who work as civil servants, private \& entrepreneurial employees with an income of an average of $\mathrm{Rp} 1,500,000$ per month.

\section{Mental Accounting in Household Financial Management}

Mental accounting as economic behavior when someone classifies inputs and outputs based on items just like the accounting model (account code). Thus, mental accounting refers to the behavior or way of thinking of someone who has a tendency to classify and treat money differently, depending on where the money comes from. [2]

Table Size of Mental Accounting in Household Financial Management

\begin{tabular}{lccccccc}
\hline Statement & STS & TS & N & S & SS & \multirow{2}{*}{ Score } & \multirow{2}{*}{ Average } \\
& 1 & 2 & 3 & 4 & 5 & & \\
& https://ijstm.inarah.co.id & & & \\
\end{tabular}




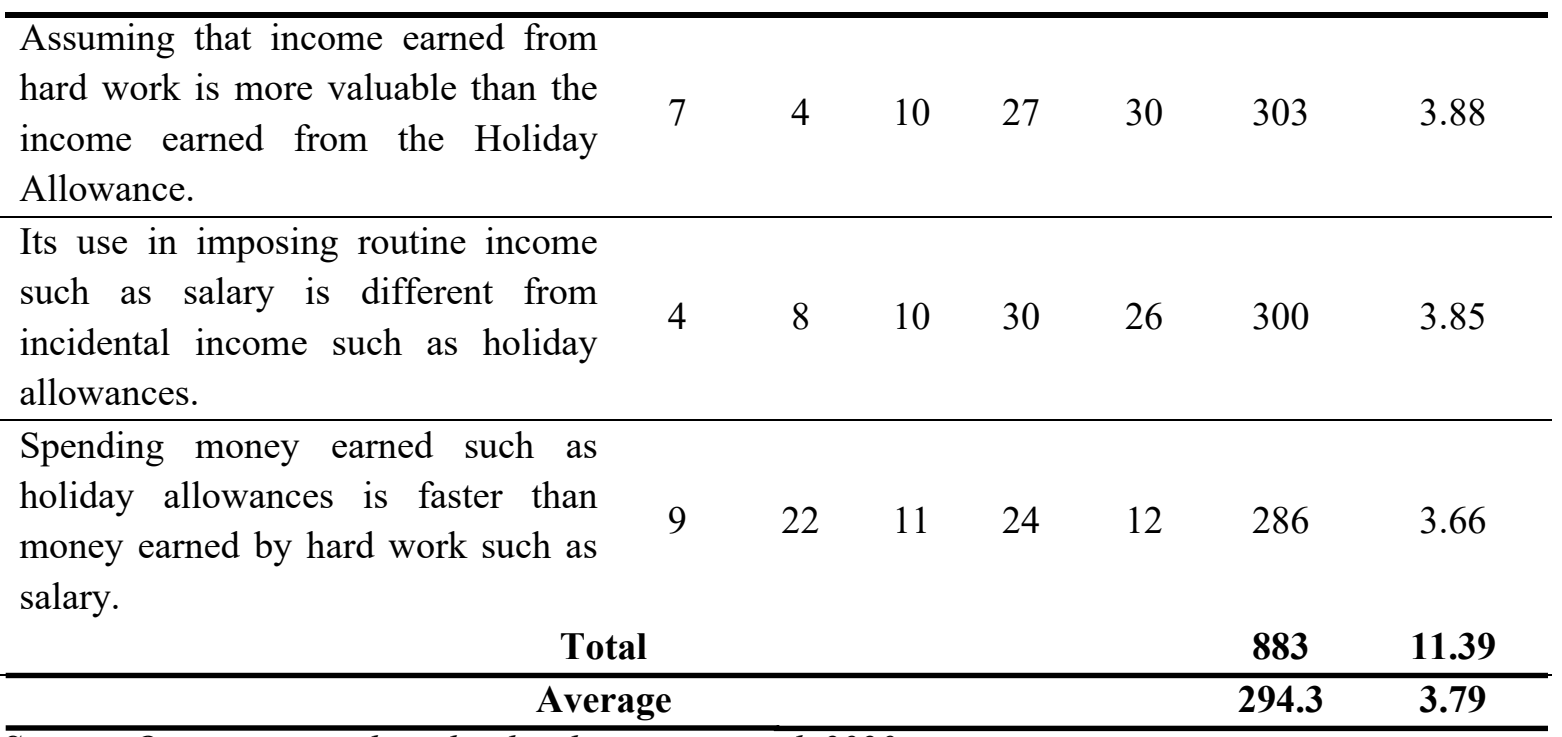

Source: Questionnaire data that has been processed, 2020

Table shows the size of mental accounting in the management of the household financial of Civil Servants of High School Teachers (SMA) in Sirimau district Ambon. A measure of mental accounting behavior is someone who has a tendency to classify and treat money differently, depending on where the money comes from. Someone groups money and treats money differently if: First, the person considers income derived from hard work to be more valuable than income derived from Holiday Allowances or incidental income. In the individual's mind, a paradigm is often formed that the income generated from hard work has more meaning or value compared to income obtained easily. Of the 78 respondents, the average of whom agreed on their daily behavior who considered income earned from hard work to be more valuable than income derived from Holiday Allowances or incidental income. The data shows the average value of the entire statement is 3.88 which is in the interval of $3.40-4.19$.

Second, the person treats routine income such as salary differently from incidental income such as Holiday Allowances. Through this research, respondents not only consider income derived from hard work such as routine salary to be more valuable than income derived from Holiday Allowances or other incidental income, but also treating money differently depending on the source of income. This is indicated by the data obtained from 78 respondents, of which the average of whom agreed to treat routine income differently from incidental income received. The average value of the entire statement is 3.85 which is in the interval 3.40 4.19 .

Third, spending money which is easily obtained like Holliday Allowances is faster than money earned by hard work such as salary. They feel that the money is earned without much effort so that it makes someone easier than the income they receive. Through this research, out of 78 respondents, on average they agreed that money from Holliday Allowances or other incidental income would run out faster than money from routine salary received per month, where the average value of the entire statement is 3.66 which is at interval $3.40-4.19$.

\begin{tabular}{lcc}
\multicolumn{4}{l}{ Tabel Size of Mental Accounting in Household Financial Management } \\
\hline Mental Accounting in Financial Management & Yes & No \\
\hline $\begin{array}{l}\text { Classifing routine income such as salaries in } \\
\text { expenditure items }\end{array}$ & $97.4 \%$ & $2.6 \%$ \\
\hline $\begin{array}{l}\text { Classifying incidental income such as THR into } \\
\text { expenditure items }\end{array}$ & $57.7 \%$ & $42.3 \%$ \\
\hline
\end{tabular}

Source: Questionnaire data that has been processed, 2020

Fourth, the person classifies input into expenditure items. Classification of the first input is to classify routine income into posts. Based on the data obtained in table 4.3, almost all respondents classified the routine income received in this case salary into expenditure items. Of 78 respondents, 2 respondents 
$(2.6 \%)$ did not classify their regular income into expenditure items. The rest, 76 respondents $(97.4 \%)$ classified their routine income into expenditure items. Classification of the second input is to classify incidental income into expenditure items that are different from expenditure items of routine income. Of 78 respondents, 33 respondents $(42.3 \%)$ did not classify incidental income into expenditure items. The remaining 45 respondents $(57.7 \%)$ classified incidental income into expenditure items whose utilization was different from expenditure items on routine income.

Based on the overall data obtained from the research results on mental accounting in the household financial management of high school teachers in Sirimau district, Ambon, it is clear that respondents tend to think partially so leading to illogical use of money use (fungibility) due to the mental accounting in household financial management of high school teachers in Sirimau district, Ambon. Therefore, mental accounting refers to the behavior or way of thinking of someone who has a tendency to classify and treat money differently, depending on where the money comes from. This behavior or method occurs when; First, they consider the income earned from hard work is more valuable than easily earned income. Second, they treat income received from routine salaries differently from income received from holliday allowances and other incidental income. Third, they spend easily-obtained money like holliday allowances faster than money obtained from hard work. Fourth, they classify income into expenditure items. Through this research, it is known that mental accounting occurs in the household financial management of high school teachers in Sirimau district, Ambon. This is evident from the statements of respondents who mostly agreed to classify and treat money differently, depending on where the money cames from.

\section{CONCLUSION}

\section{Conclusion}

The research aimed to prove the existence of mental accounting in financial management and the impact on civil servants of high school teachers in Sirimau district, Ambon. The findings of this research indicate that mental accounting occurs in household financial management. In managing household finances, teachers tend to think partially leading to the illogical use of money (fungibility) and income allocation to be biased while incidental income is more widely used for consumptive purposes.

Chattereje, Heath and Min Arevealed that mental accounting can have an adverse impact on decision making. However, Karlsson and Hoch and Loewenstein stated that mental accounting can be used as a selfcontrol device. This means that even though someone thinks irrationally, it does not always have a negative impact. This research contrasts with Chattereje et al, but supports Karlsson and Hoch and Loewenstein. [28]; [29]; [30]

\section{Suggestion}

This research was conducted using a survey method with questionnaire technique, where the instrument was made by the researcher so that it is still not standard. It is expected that further research can re-test the instrument. Research with the topic of mental accounting is still relatively small, so it is still possible to do the same research from the opinions of different experts about mental accounting.

\section{Thank-You Note}

On this occasion I would like to say thank you to the Indonesian research institute of Indonesian molucan who has funded this research

\section{REFERENCES}

[1] Supramono, Kaudin.A, Mahastanti.L.A \& Damayanti. T.W (2010). Desain Penelitian Keuangan Berbasis Perilaku. FEB UKSW.

[2] Bonini, N, \& Rumiati, R. (2002). Acceptance of a price discount: The role of the semantic relatedness between purchases and the comparative price format. Journal of Behavioral Decision Making, 15, 203-220.

[3] --------ontal (1996). Mental accounting and acceptance of a price discount. Acta Psychologica, 93, 149-160. 
[4] Belsky \& Gilovich (2009). Why Smart people make Big Money Mistake and how to correct them. Lesson from the life- changing science of behavioral economics. New York.

[5] Chatterjee, S; Heath, T.B \& Min, J (2009 The Susceptibility of Mental Accounting Priciple of Evaluation Mode Effects, Journal of Behavioral Decision Making, 22: 120-137

[6] Cheema, A, \& Soman, D. (2006). Malleable mental accounting: The effect of flexibility on the justification of attractive spending and consumption decisions. Journal of Consumer Psychology, 16, 33-44

[7] Gudono \& Hartadi. B. (1998). Apakah Teori Prospek Tepat untuk Kasus Indonesia?: Sebuah Replikasi Penelitian Tversky and Kahneman. Journal Riset Akuntansi Indonesia. Vol.1 No. 1:29-42

[8] Heath, C. \& SoIl, J. B. (1996) 'Mental accounting and consumer decisions', Journal of Consumer Research, 23, 40-52.

[9] Heath, T.B., Chatterjee S., \& France K.R. (1995). Mental accounting and changes in price: The frame dependence of reference price. Journal of Consumer Research, 22, 90-97.

[10] Henderson, P. \& Peterson, R. (1992) 'Mental accounting and categorization', Organizational Behavioral and Human Decision Processes, 51, 92-117

[9] Hoch. S.J., \& Loewenstein. G.F (1991). Time-inconsistent preferences and consumer self-control. Journal of Consumer Research, 17, 492-507

[10] Joyce, E.J., \& Shapiro, B.P. (1995). Invariance violations and mental accounting procedures in riskless matching. Organizational Behavior and Human Decision Processes, 62, 175-189.

[11] --------. (1984). Choices, values, and frames. The American Psychologist, 39, $341-350$.

[12] Kahneman, D \& Tversky. (1979). A. 'Prospect theory: an analysis of decision under risk', Econometrica, 47, 263-291

[13] Karlsson. N, (1998). Mental Accounting And Self Control, Goteborg Psychological Reports, 28, No 22. Sweden: Goteborg University, Depatement of Psychology.

[14] Keller, C \& Siegrist, M. (2004). 'Money Attitudes, Demographics, and Money Behaviors: Development of a Money Attitudes Scale', Working Paper

[15] Langer, T., \& Weber, M. (2001). Prospect-theory, mental accounting, and differences in aggregated and segregated evaluation of lottery portfolios. Management Science, 47, 716-733.

[16] Lim, S. (2009). The Role of Proportional Bias in Mental Accounting. Thesis

[17] --------. (2006). Do investors integrate losses and segregate gains? Mental accounting and investor trading decisions. 2006. Journal of Business 79 (5): 2539-2573.

[18] Phung, A. (2007). Behavioral Finance: Key concepts Confirmation and Hindsight Bias. http://www.investopedia.com. Diunduh tanggal 2 Juli 2010

[19] Supramono \& Utami.I, (2004). Desain Proposal Penelitian Akuntansi\&Keuangan. Yogyakarta, Andi

[20] Suryobroto (2007). Apa yang Mempengaruhi Perencanaan Keuangan Anda?. http://belajarmanagement.wordpress.com. Diunduh tanggal 29 Juli 2010

[21] Shefrin, H. H. \& Thaler, R. H. (1988). 'The behaviorallife-cycle hypothesis', Economic Inquiry, 26(October), 609-643.

[22] Statman, M. (2002) "Financial Physicians." AIMR Conference Proceeding, Investment Counseling for Private Clients IV, pp. 5-11.

[23] Thaler R., (1998), Mental Accounting Matters, Journal of Behavioral Decision Making, n. 12, pp. $183-206$.

[24] ---------, (1985). Mental accounting and consumer choice. Marketing Science 4 (3): 199214.

[25] Thaler, R., \& E. Johnson. 1990. Gambling with the house money and trying to break even: the effects of prior outcomes on risky choice. Management Science 36(6): 643-660.

[26] Tversky, A. \& Kahneman, D. (1981). 'The framing of decisions and the rationality of choice', Science, $211,453-$ 458.

[27] Yulis.I (2010). Kecerdasan Finansial \& Kecerdasan Emosianal dalam Pengelolaan Keuangan. Studi Pada Ibu Rumah Tangga Wilayah Kentangan, Jagalan di Semarang. Tesis 